\title{
On the need to develop strategic directions for the formation of a comfortable living environment based on the needs of older adults
}

\author{
Irina Saenko ${ }^{1}$, Kristina Chepeleva $^{1,2, *}$, and Olga Tolochko ${ }^{1}$ \\ ${ }^{1}$ Siberian Federal University, Svobodny pr., 79, 660041 Krasnoyarsk, Russia \\ ${ }^{2}$ Krasnoyarsk State Agrarian University, Mira Avenue, 90, 660049 Krasnoyarsk, Russia
}

\begin{abstract}
The article presents the results of assessment of the conformity of the existing living environment and identification of features of its development, based on the needs of older adults. The urbanization of society and the aging of the population are one of the factors that have recently given rise to the forms of development of the residential environment, which determine special organizational, managerial, and urban planning decisions for designing the parameters of residential buildings and housing stock, based on the needs of this category of citizens. Strategic tools made it possible to outline the main directions for the development of a comfortable living environment, based on the needs of older adults. The developed roadmap provides for the optimization of the existing regulatory framework for the design of residential areas and the popularization and implementation of new standards for integrated development. A city designed according to standards that meet the needs of various categories of citizens determines their choice of alternative social models of the living environment.
\end{abstract}

\section{Introduction}

In the first third of the last century, a person acted in architecture as a functional unit with a minimum set of personal needs. However, only 30 years later, in the sixties of the XX century, an understanding of the direct relationship between the processes, trends formed in society and architecture came, and a person with his needs acquired a new role as a subject of social interaction.

Modern post-industrial format of the innovative vector of the social order brought to the fore the problem of human interaction with his environment. A new concept of the work of architects has appeared, stating that now it is not a person who adapts to the environment, but the environment acquires other properties based on the needs and desires of a person $[1]$.

In the market for goods and services, where there's demand, there's supply. The consumer market for older adults has a wide range of products and services offered,

* Corresponding author: kristychepeleva@mail.ru 
including the development of a specialized real estate market. This segment of the real estate market has a huge growth potential. Considering the characteristics of older adults as a growing group of consumers plays a role in economic development, as the generation of new markets with a wide variety of goods and services for all ages is beneficial to all participants, including older adults themselves [2].

The formation of a new consumer group as older adults is indicative of some demographic trends. Russian statistics show the aging process of the population, i.e. the proportion of older citizens in relation to the country's population is becoming larger, as well as the proportion of citizens over working age. This, in turn, is due to an increase in life expectancy and a decrease in the total fertility rate.

Over time, this social group of citizens thus pays attention to its specificity of life. It is obvious that elderly people need a special attitude due to their physical capabilities [3, 4]. A number of factors such as pathologies of the organs of hearing, vision, and the musculoskeletal system determine the level of increased comfort in the environment, and it is specialized housing that is designed to meet these requirements [5].

According to the average variant of the UN forecast, the proportion of citizens aged 60 and over:

- $\quad$ will increase globally from $12.3 \%$ in 2015 to $14.9 \%$ in 2025 and $21.5 \%$ in 2050 ;

- $\quad$ in Europe - from $23.5 \%$ in 2015 to $28 \%$ in 2025 and $34.2 \%$ in 2050 ;

- $\quad$ in the Russian Federation - from $20 \%$ in 2015 to $23.9 \%$ in 2025 and $28.8 \%$ in 2050.

According to the average version of the forecast of the Federal State Statistics Service, the proportion of citizens over working age in the Russian Federation will increase from $24.6 \%$ in 2016 to $27 \%$ in 2025 and will amount to 39.9 million people.

In total, all of the above factors and trends in various spheres of society set new organizational, managerial, urban planning tasks and goals for the state and society. They are aimed not only at meeting the basic needs of older adults to maintain living conditions, but also at creating conditions for their active participation in political, social, and other spheres of society. The latter, in turn, entails the creation of various kinds of plans and strategies, national projects, federal and regional programs to provide a comfortable living environment for older adults.

The objective of the research is to develop strategic directions for the formation of a comfortable living environment for older adults.

The object of the study is the comfort of the living environment for older adults in the Russian Federation and Krasnoyarsk.

The subject of the research is tools for creating a comfortable living environment for older adults.

\section{Materials and Methods}

Development of strategic directions for the formation of a comfortable living environment based on the needs of older adults requires analyzing such an environment. To complete this task, the authors used tools such as PEST and SWOT analysis, sociological survey, analysis of stakeholders, and statistical data analysis.

Structuring of existing programs and methods for providing a comfortable living environment is based on their division by levels of implementation, namely international, all-Russian, and regional levels. For the analysis of the programs, the most priority area for research was identified - housing construction in various Projects, Programs, and Strategies of the Russian Federation.

The structured system of projects to ensure a comfortable environment for older adults helps note that during the transition from the international level to the regional level (on the 
example of the Russian Federation and the Krasnoyarsk Territory) the implementation of these projects loses a whole line of development of non-stationary specialized housing integrated into residential development, customized to the needs of older adults, as well as the design of a combined comprehensive development considering the needs of not only the working-age population, but also older adults, as a new growing group of consumers.

Action from the Madrid Plan to create favorable conditions through improved planning and a different number of urban planning solutions find its application in the Strategy of the Russian Federation through the development of design solutions and improvement of conditions in isolated and stationary specialized institutions, omitting the development of design solutions with the possibility of having their own housing as an element of the general residential development of the city.

Analysis of stakeholders (population, authorities, media, participants in the construction industry, scientific community, and ordinary employees of organizations) showed that the authorities (federal, regional, municipal) and participants in the construction industry have the greatest influence on a comfortable living environment for older adults. The target population does not influence significantly, but has great opportunities for affecting the formation of the comfort of the environment. The potential of second-line stakeholders (universities, academia, research centers, media) can be converted to their advantage and turned into stakeholders of great opportunities. In particular, we are talking about research centers and design institutes. Sociological studies of the needs in the living environment for various groups of the population help to reduce threats from threatening stakeholders (construction companies), and various design solutions can answer the question of "How to put the proposed strategy into practice?"

As part of the research topic, an assessment of the urban environment was carried out based on the analysis of a GoogleForms-based survey of city residents. The survey involved 135 people, which with a 1 million population of Krasnoyarsk estimates the situation with an error of $+/-10 \% .86 .7 \%$ of respondents, when older, do not want to live apart from society in a specialized institution, but prefer their own housing. $80.3 \%$ of respondents believe that the city's residential areas do not meet the needs of the elderly. The respondents note that modern residential development is more focused on young families with children or young people in general. Inconvenient for older people bus boarding area slopes to the roads, wide-pitch stairs without handrails, lack of social infrastructure (special-interest clubs), etc.

The sociological study of the Center for Civil Society Research and the Non-Profit Sector of the Higher School of Economics "Problems of Determination of Public Activity of Russians" revealed four main lifestyles of older people: family-focused; focused on status, well-being and wealth; socially active pensioner; detached from society and focused on their own health. This classification reflects differences in needs even within one social group, such as older adults $[6,7]$.

To identify political, economic, social, and technological aspects that influence the formation of a comfortable living environment, a PEST analysis was applied (Table 1).

Table 1. PEST factors that influence the formation of a comfortable living environment for older adults

\begin{tabular}{|c|c|}
\hline Factors & Influence \\
\hline \multicolumn{1}{|c|}{ Political and legislative factors } \\
\hline & \\
- updating the regulatory framework & - allows demanding the high-quality urban \\
- creation of development standards & planning from developers \\
- comfortable environment programs. &
\end{tabular}


Table 1. Continued

\begin{tabular}{|c|c|}
\hline \multicolumn{2}{|c|}{ Economic factors } \\
\hline $\begin{array}{c}\text {-state and municipal programs aimed at } \\
\text { stimulating the housing sector and creating a } \\
\text { comfortable environment } \\
\text { - the economic situation in the country }\end{array}$ & $\begin{array}{l}\text { - allows making housing more affordable, } \\
\text { creating a comfortable environment. } \\
\text { - stagnation or recession of the real estate } \\
\text { market due to a poor economic situation } \\
\end{array}$ \\
\hline \multicolumn{2}{|c|}{ Social factors } \\
\hline $\begin{array}{l}\text { - demographic factors } \\
\text { - changing lifestyle } \\
\text { - increasing requirements for the quality } \\
\text { of the environment }\end{array}$ & $\begin{array}{l}\text { - the emergence of market proposals } \\
\text { oriented to the needs of the population }\end{array}$ \\
\hline \multicolumn{2}{|c|}{ Technological factors } \\
\hline $\begin{array}{l}\text { - aging of the serviced housing stock } \\
\text { - application of new technologies and } \\
\text { materials } \\
\text { - application of modern approaches in } \\
\text { design }\end{array}$ & $\begin{array}{l}\text { - a decrease in favorable living conditions, } \\
\text { an increase in the depreciation of the housing } \\
\text { stock } \\
\text { - an increase in competition for the } \\
\text { consumer due to improved quality of projects }\end{array}$ \\
\hline
\end{tabular}

PEST analysis showed that social factors, in particular the demographic situation and the increase in the number of older adults, as well as their changing lifestyle and increased attention to the quality of residential facilities and the comfort of the environment, have a significant impact. Technological factors also have a significant impact, which are expressed in the emergence of modern technologies and materials, new approaches in the design of residential complexes, which entails the government's attention to these issues and the emergence of various projects, programs and strategies aimed at creating a comfortable environment.

To develop a development strategy for a comfortable environment based on the needs of older adults, a SWOT analysis was performed (Table 2).

Table 2. SWOT analysis of the living environment and urban areas of Krasnoyarsk

\begin{tabular}{|c|c|}
\hline Opportunities (O) & Strengths (S) \\
\hline $\begin{array}{l}\text { - intensification of competition for the } \\
\text { consumer between developers } \\
\text { - increased public demand for a comfortable } \\
\text { living environment } \\
\text { - meeting the needs of a special category of the } \\
\text { population in comfortable housing }\end{array}$ & $\begin{array}{l}\text { - the appearance of new projects of the } \\
\text { European level on the market, which can lead to a } \\
\text { shift in the minds of consumers and developers } \\
\text { - public-private partnership allows creating a } \\
\text { comfortable environment in a shorter time }\end{array}$ \\
\hline Threats $(T)$ & Weaknesses (W) \\
\hline $\begin{array}{l}\text { - deteriorating economic situation in the } \\
\text { country } \\
\text { - price risks associated with high housing } \\
\text { prices relative to household income } \\
\text { - monopoly of developers }\end{array}$ & $\begin{array}{l}\text { - use of outdated urban planning approaches } \\
\text { - ill-considered planning decisions for older } \\
\text { adults } \\
\text { - social infrastructure is being built with a great } \\
\text { delay } \\
\text { - poor green spaces, parks and walking areas } \\
\text { - ill-considered transport component }\end{array}$ \\
\hline
\end{tabular}

The SWOT matrix shows enough weaknesses in the formation of a comfortable environment in Krasnoyarsk. A poor-quality environment is created, integrity in the classical sense (housing and infrastructure) is absent, and the threats of the economic factor ca cancel out all potential opportunities. 


\section{Results and Discussion}

The development of residential housing involves an increase in the level of comfort of the environment, therefore, it is relevant to adhere to a strategy focused on improving the quality of real estate objects (Table 3 ).

The first step to start with is to optimize the existing regulatory framework. This is the creation of local architectural regulations and design principles. At the federal level, this is the development of principles for integrated development, reflecting the vision of modern integrated development of territories in terms of planning decisions and technical and economic indicators of development, making changes or developing new regulatory documents regulating urban planning activities aimed at improving the comfort of the environment in accordance with the Code of Principles for Integrated Development, Strategy, MDS 35.12-2006 and other regulatory documents.

In parallel with the work on the regulatory framework, an active marketing campaign should be carried out among the population and developers in order to create demand and supply, respectively, for projects based on new urban planning principles for individual target audiences.

Table 3. Roadmap for a comfortable living environment based on the needs of older adults

\begin{tabular}{|c|c|c|}
\hline No. & Implementation phase & Target value of the indicator / expected result \\
\hline 1 & \multicolumn{2}{|c|}{ Updating the regulatory framework } \\
\hline 1.1 & $\begin{array}{l}\text { Revision of the regulatory framework for the } \\
\text { design of residential areas in terms of norms for } \\
\text { the mandatory area of functional zones to increase } \\
\text { the compactness of development }\end{array}$ & $\begin{array}{l}\text { Development density up to } 25 \text { thousand } \mathrm{m}^{2} / \mathrm{ha} \\
\text { Degree of development } 20-35 \% \\
\text { Population density up to } 500 \text { people/ha } \\
\text { Street-road network density } 10-30 \mathrm{~km} / \mathrm{km}^{2} \\
\text { (depending on the development) } \\
\text { Green areas } 25-35 \% \\
\text { Availability of parking spaces } 200-400 \\
\text { places/1000 residents }\end{array}$ \\
\hline 1.2 & $\begin{array}{l}\text { Creation of programs for the development of } \\
\text { residential buildings }\end{array}$ & $\begin{array}{l}\text { Availability of programs that directly address } \\
\text { the needs and capabilities of older people }\end{array}$ \\
\hline 2 & \multicolumn{2}{|c|}{ Popularization and implementation of new standards } \\
\hline 2 & $\begin{array}{l}\text { Implementation and popularization of } \\
\text { integrated development standards }\end{array}$ & $\begin{array}{l}\text { Number of projects } \\
(60 \% \text { of total })\end{array}$ \\
\hline 2.1 & $\begin{array}{l}\text { Communication of new provisions of the } \\
\text { regulatory framework to ordinary employees }\end{array}$ & $\begin{array}{l}\text { Communication of principles to employees } \\
\text { through the management, thereby informing the } \\
\text { threatening stakeholders (managers, realtors). }\end{array}$ \\
\hline 2.2 & $\begin{array}{l}\text { Coverage of standards in the media, } \\
\text { formation of the population's request for a } \\
\text { comfortable living environment }\end{array}$ & $\begin{array}{l}\text { Number of materials released by the media } \\
\qquad(700-1000, p c s)\end{array}$ \\
\hline 2.3 & $\begin{array}{l}\text { Distribution of regulatory documents to city } \\
\text { administrations and construction companies }\end{array}$ & $\begin{array}{c}\text { Principles will be disseminated to stakeholders } \\
\text { with a high level of opportunities }\end{array}$ \\
\hline 2.4 & $\begin{array}{l}\text { Organization and conduct of free training courses } \\
\text { for architects, developers }\end{array}$ & $\begin{array}{c}\text { Number of applications for participation in } \\
\text { courses }(30,000, \mathrm{pcs})\end{array}$ \\
\hline 2.5 & $\begin{array}{l}\text { Creation and support of competitions for the } \\
\text { best projects for the development of residential } \\
\text { buildings, planning of residential premises }\end{array}$ & $\begin{array}{l}\text { Number of completed projects } \\
\qquad(600, \text { pcs })\end{array}$ \\
\hline 2.6 & $\begin{array}{l}\text { Mandatory introduction of an updated regulatory } \\
\text { framework }\end{array}$ & $\begin{array}{l}\text { Active application of the "Code of Integrated } \\
\text { Development Principles" in real production }\end{array}$ \\
\hline
\end{tabular}

The comfortable environment includes not only the living space of apartments, but also implies the comfort of the microdistrict - a residential quarter. Therefore, among other things, the existing and fundamental principles of new urbanism can be appropriately applied to create a comfortable environment: pedestrian accessibility; the interconnectedness of the road network; mixed use (multifunctionality) and a variety of objects within the microdistrict; high-quality planning of architectural objects of the city, high-quality public transport; maintaining the traditional structure of the neighborhood, 
which consists in comfortable and safe living on a single territory of various social groups of the population $[8,9]$, is an important task of the residential development program, etc.

\section{Conclusions}

1. The existing urban patterns of older people need to be modernized. Against the background of changes in the age-related model of human employment and the system of world views on importance of the comfort of urban citizens, the authors revealed inconsistency of the existing urban environment with the needs of older adults.

2. New methods of assisting and caring for older people, such as maintaining active longevity through socialization with other groups (young people and children) and occupational therapy, require different architectural and spatial forms and organizational and managerial decisions.

3. Implementation of the necessary set of urban planning, organizational, and management decisions aimed at improving the quality of life of older people, requires changes in existing government programs, the development of new strategic directions for the formation of a comfortable living environment for the population based on the interests of all categories of citizens.

\section{References}

1. E.V. Sonyak, Architecton journal, 22 (2008)

2. Strategy of Actions for the Benefit of Senior Citizens in the Russian Federation until 2025 (2016)

3. P. Bhasha, T. Pavan Kumar, K.K. Baseer, Journal of advanced research in dynamical and control systems, 12 (2020)

4. L.T. Wong, K.N.K. Fong, K.W. Mui, W.W.Y. Wong, L.W. A. Lee, Indoor and built environment, 18 (2009)

5. A.S. Grishkina, News of KSASU, 1 (2013)

6. M.E. Troian, Architecture and Modern Information Technologies, 1 (2020)

7. V. P. Generalov, E. M. Generalova, IOP Conf. Ser.: Mater. Sci. Eng., 775 (2020)

8. L. Logunova, E. Mazhenina, N. Nyatina, Advances in social science, education and humanities research, 331 (2019)

9. Saenko, K. Chepeleva, V. Sarchenko, Espacios, 38 (2017) 